\title{
Biochar application in alkaline soil and its effect on soil and plant
}

\author{
Tamer Mohamed SALEM ${ }^{1,2}$, Khaled Mohamed REFAIE ${ }^{3}$, Abd El-Hamid El-Ghadban Abd El-Lateif \\ SHERIF $^{1}$, Mohamed Ahmed Mohamed EID ${ }^{1}$
}

Received September 10, 2018; accepted August 22, 2019. Delo je prispelo 10. septembra 2018, sprejeto 22. avgusta 2019.

\section{Biochar application in alkaline soil and its effect on soil and plant}

Abstract: Scientists reported that biochar can improve soil properties in acidic soils, while in alkaline soils were shown negative results. A field study was done to evaluate the effect of biochar application solely in alkaline soil compared with biochar composts with farm yard manure (BC-FYM) and sulfur (BC-S). The results revealed that using solely biochar decreased yield of potatoes tubers to more than $6 \%$ and $10 \%$ using mineral and organic fertilization, respectively. This was attributed to the alkalinity effect of biochar and raises the soil $\mathrm{pH}$, which might precipitate macro and micro elements in soil and become unavailable for plant absorption. While using mixtures of BCFYM and BC-S were shown to enhance yield productivity of potatoes tubers $11.7 \%$ and equal to control under mineral fertilization; and $25.13 \%$ and $10.53 \%$ using organic fertilization, respectively. Mixture of BC-FYM and BC-S proved to have the ability for recovering the alkalinity effect of biochar, improve nutrients availability in soil and increase crop yield of potatoes. In general, mixing biochar with FYM was efficient, economical and environmentally sound solution in alkaline soils.

Keywords: biochar; alkaline soil; potatoes; nutrient availability; crop yield
Uporaba oglja na alkalnih tleh in učinek na tla in rastlino

Izvleček: Znanstveniki poročajo, da uporaba oglja izboljša lastnosti kislih tal, medtem ko so učinki na alkalnih tleh negativni. $\mathrm{V}$ poljskem poskusu so bili ovrednoteni učinki uporabe samo oglja $\mathrm{v}$ primerjavi $\mathrm{z}$ njegovo kombinacijo s hlevskim gnojem (BC-FYM) in žveplovimi spojinami (BC-S). Rezulati so pokazali, da je uporaba samo oglja zmanjšala pridelek krompirja za več kot $6 \%$, oziroma $10 \%$, ko je bilo gnojeno $\mathrm{z}$ mineralnimi in organskimi gnojili. To je bila posledica alkalnega učinka oglja preko dviga $\mathrm{pH}$ tal, kar je lahko oborilo mikro in makro elemente in jih naredilo nedostopne za prevzem $\mathrm{v}$ rastline. Uporaba mešanic BC-FYM in BC-S je povečala pridelek gomoljev krompirja za 11,7 \%, kar je bilo enako kontrolnemu obravnavanju pri gnojenju $\mathrm{z}$ mineralnimi $(25,13 \%)$ in organskimi (10,53 \%) gnojili. Mešanica BC-FYM in BC-S je imela dokazano sposobnost blaženja alkalnega učinka oglja, kar je izboljšalo dostopnost hranil $\mathrm{v}$ tleh in povečalo pridelek gomoljev krompirja. Nasplošno je bilo mešanje oglja s FYM učinkovita, ekonomsko in okoljsko dobra rešitev na alkalnih tleh.

Ključne besede: oglje; alkalna tla; krompir; dostopnost hranil; pridelek

1 Soils, Water and Environment Research Institute (SWERI), Agricultural Research Center (ARC), Giza, Egypt.

2 Corresponding author, e-mail: tamer_salem43@yahoo.com

3 Application Dept., Central Laboratory for Agricultural Climate, Agricultural Research Center (ARC), Dokki, Giza, Egypt. 


\section{INTRODUCTION}

Biochar is a carbon $(\mathrm{C})$-rich product obtained by thermal decomposition of biomass at relatively high temperatures $\left(<700^{\circ} \mathrm{C}\right)$ and absence of oxygen, in a process known as pyrolysis (Verheijen et al. 2010). Biochar claimed to have potential benefits for soil including water holding capacity (Busch et al., 2012; Busscher et al., 2010; Kammann et al., 2012; Karhu et al., 2011), water infiltration (Asai et al., 2009; Ippolito et al., 2012), soil water availability (Baronti et al., 2014), nutrient retention (Clough et al., 2013; Ventura et al., 2013), hydraulic conductivity (Buss et al., 2012), and soil aeration (Case et al., 2012; Cayuela et al., 2013), increased microbial activity (Lehmann et al., 2011; Warnock et al., 2007), shifts in microbial diversity (Jin, 2010), increase in electrical conductivity (Husson, 2012) and immobilization of contaminants such as trace elements (especially $\mathrm{Cu}$ ) (Borchard et al., 2012; Buss et al., 2012; Ippolito et al., 2012) or pesticides (Gomez-Eyles et al., 2013; Graber et al., 2012). However, significant increase in soil fertility, plant growth and yield was reported due to biochar application in tropical and subtropical soils (Asai et al., 2009; Atkinson et al., 2010; Glaser et al., 2002; Lehmann and Rondon, 2006; Lehmann and Steiner, 2009a; Major et al. 2010). This was attributed to the liming effect of biochar which decrease significantly soil acidity, resulting in better conditions for growing crops (Steiner et al. 2007; Yuan and Xu2011). The application of biochar in alkaline soils showed different effects: the application of biochar solely lead to reduction in crop yield in alkaline soil. This was reported by many scientists (Ding et al., 2010; Graber and Elad, 2013; Jin, 2010; Taghizadeh-Toosi et al., 2011) who referred this effect to nutrients adsorption onto biochar surface (e.g. the adsorption of ammonium, phosphate and other cations). Consequently, to avoid the alkalinity effects of biochar, different suggestions were proposed, such as enhancement of biochar with organic or mineral nutrients (Alburquerque et al., 2012; Bruun et al., 2011; Gathorne-Hardy et al., 2009; Joseph et al., 2013a, b), composting BC with compost (Fischer and Glaser, 2012; Steiner et al., 2010), charge the porous biochar matrix with nutrients, stimulate microbial colonization (Pietikäinen et al., 2003), reduce noxious pyrogenic materials during production of BC (Tuomela et l., 2000), or increase the biochar surface reactivity using enhanced oxidative ageing (Cheng and Lehmann, 2009b; Zimmerman, 2010) as well as DOC adsorption (Prost et al., 2012). Thus, in the present study, we aimed to reduce alkalinity effect of $\mathrm{BC}$ through composting $\mathrm{BC}$ with farmyard manure (BC-FYM) and sulfur (BC-S) for enhancing the elements availability, crop yield and crop quality in alkaline soil as compared with freshly produced biochar (BC) under recommended mineral and organic fertilizer conditions.

\section{MATERIALS AND METHODS}

\subsection{PRODUCTION OF BIOCHAR}

Eggplant shoots were used to synthesize BC under low oxygen conditions using small-scale unit. The unit was designed as described by Abd el-hafez et al (2014). Briefly, barrel with a diameter of $55 \times 85 \mathrm{~cm}$ was served as a burning barrel. For the lid, a well tight lid of the burning barrel with another half barrel inverted and supported with $20 \mathrm{~cm}$ diameter chimney tube was used to

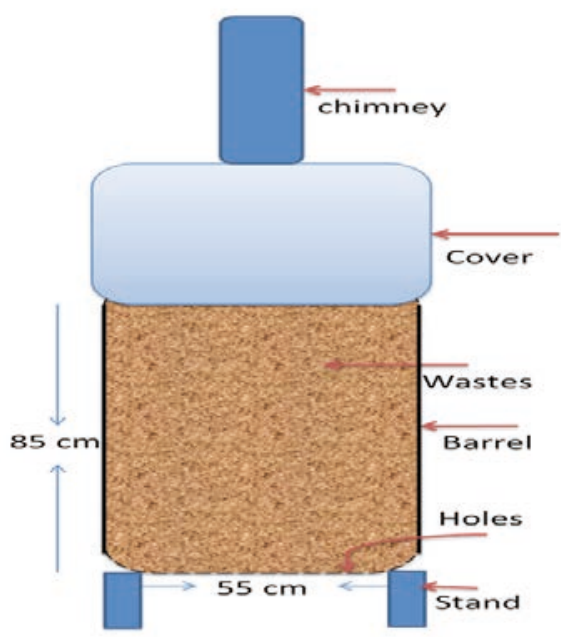

Figure 1: Scheme of designed unit for biochar production. 
Table 1: Physical and chemical characteristics of the experimental soil

\begin{tabular}{|c|c|c|c|c|c|c|c|c|c|c|c|c|}
\hline \multirow[b]{2}{*}{ Soil depth } & \multicolumn{7}{|c|}{ Particle size distribution \% } & & \multirow[b]{2}{*}{ Texture class } & \multirow[b]{2}{*}{ OM \% } & & \multirow[b]{2}{*}{$\mathrm{CaCO}_{3} \%$} \\
\hline & \multicolumn{2}{|c|}{ Coarse sand } & \multicolumn{2}{|c|}{ Fine sand } & \multicolumn{2}{|l|}{ Silt } & \multicolumn{2}{|l|}{ Clay } & & & & \\
\hline $0-20$ & 6.18 & & 19.4 & & 37.3 & & 36.6 & & Clay loam & \multicolumn{2}{|l|}{2.80} & 1.85 \\
\hline $20-50$ & \multicolumn{2}{|l|}{13.2} & \multicolumn{2}{|l|}{26.0} & \multicolumn{2}{|l|}{33.3} & \multicolumn{2}{|l|}{29.5} & Clay loam & \multicolumn{2}{|l|}{2.70} & 2.20 \\
\hline \multirow[t]{2}{*}{$50-70$} & \multicolumn{2}{|l|}{10.5} & \multicolumn{2}{|l|}{20.5} & \multicolumn{2}{|l|}{35.2} & \multicolumn{2}{|l|}{33.8} & Clay loam & \multicolumn{2}{|l|}{2.38} & 2.25 \\
\hline & \multirow[b]{2}{*}{$\mathrm{pH}$} & \multirow{2}{*}{\multicolumn{2}{|c|}{$\begin{array}{l}\mathrm{EC} \\
\left(\mathrm{dS} \mathrm{m}^{-1}\right)\end{array}$}} & \multicolumn{4}{|c|}{ Soluble anions $\left(\mathrm{mmol} \mathrm{l}^{-1}\right)$} & & \multicolumn{3}{|c|}{ Soluble cations $\left(\mathrm{mmol} \mathrm{l}^{-1}\right)$} & \\
\hline Soil depth & & & & $\mathrm{CO}_{2}^{--}$ & & $\mathrm{HCO}_{3}^{-}$ & $\mathrm{Cl}^{-}$ & $\mathrm{SO}_{4}^{--}$ & $\mathrm{Ca}^{++}$ & $\mathrm{Mg}^{++}$ & $\mathrm{Na}^{+}$ & $\mathrm{K}^{+}$ \\
\hline $0-20$ & 7.93 & 3.41 & & 0.00 & & 1.80 & 26.70 & 4.50 & 9.20 & 6.40 & 19.90 & 0.50 \\
\hline $20-50$ & 8.01 & 3.52 & & 0.00 & & 2.20 & 25.30 & 6.50 & 10.00 & 5.50 & 18.00 & 0.50 \\
\hline $50-70$ & 8.02 & 2.32 & & 0.00 & & 1.70 & 14.60 & 3.70 & 9.00 & 3.20 & 10.50 & 0.30 \\
\hline
\end{tabular}

cover the burning barrel (Fig. 1). The unit was stroked from the bottom in addition to three metal sheets were placed at the bottom of the unit to guarantee that the air derives up regularly. The produced biochar was denoted as BC. Then, BC was mixed and composted with farmyard manure (BC-FYM) and/or sulfur (BC-S) with a ratio of 1:1 (mass/mass) for 3 months. The stack was covered, stirred and moisturized every week. The final products were added to soil during soil preparation two week before sowing day. Different physical and chemical analyses were done on initial unfertilized soil as described below (Table 1).

\subsection{EXPERIMENT SETUP}

The investigation was carried out in Dokki site ElGiza governorate, Egypt which is situated at $30^{\circ} 03^{\prime} \mathrm{N}$ latitude, $31^{\circ} 20^{\prime} \mathrm{E}$ longitude during winter time of 2015 and 2016 to explain the effect of modified BC on growth and yield of potatoes (Solanum tuberosum L.) grown in alkaline soil. A field experiment was done at a clay loam soil, around $250 \mathrm{~m}^{2}$ were roared and cleaned from weeds. This land was divided into plots $(3 \times 3.5 \mathrm{~m})$, These treatments were evaluated at two kinds of fertigation (mineral and organic). Split plot design was used in this experiment as follows: main plots were divided into 1) mineral fertigation and 2) organic fertigation, while sub-main plots were used the different $\mathrm{BC}$ treatments including ( $\square$ ) control, ( $\square$ ) BC, ( $\square$ ) BC-FYM, and ( $\square$ ) BC-S. BC dose was fixed at $12 \mathrm{Mg} \mathrm{ha}^{-1}$ for each kind of BC. Each treatment was replicated three times. Required quantities of $\mathrm{BC}$ were added to the selected treatment plots and were mixed thoroughly with the soil using spade at January two weeks before sowing date. The recommended dose of NPK nutrients were added to all mineral fertilization treatments (including control) through ammonium sulphate, mono superphosphate and potassium sulphate, respectively. While full doses of $\mathrm{P}$ were applied as basal with $\mathrm{BC}, 50 \%$ of the $\mathrm{N}$ and $\mathrm{K}$ doses were applied as basal and the remaining $50 \%$ were top-dressed after 1 month from planting. Organic fertilization $\left(30 \mathrm{t} \mathrm{h}^{-1-}\right)$ was applied according to $\mathrm{N} \%$ before sowing with two weeks. Each plot was divided into three rows (width $90 \mathrm{~cm}$ and highest $30 \mathrm{~cm}$ ). A tunnel was made in each row and tubers ('Spunta') were planted by hand at $10 \mathrm{~cm}$ depth and $25 \mathrm{~cm}$ spacing between tubers, then tunnels were covered with soil and the field was irrigated using drip irrigation. The soil was irrigated when required, and was kept weedfree by hand weeding.

\subsection{EXPERIMENTAL ANALYSIS}

Total $\mathrm{N}$ of biochar was determined in the supernatant of digested biochar by mixture of sulfuric and salicylic acid using Kjeldahl method according to Jones J. Benton. (1991), while total C of biochar was measured following ASTM1762-84 (American Standard of Testing Material, 2001). EC and $\mathrm{pH}$ of biochar was determined as described by Masulili et al (2010). Briefly, $1 \mathrm{~g}$ of material was dissolved in $100 \mathrm{ml}$ de-ionized water under heating to $90^{\circ} \mathrm{C}$ and stirred for 20 minutes. Then the suspensions were cooled to room temperature which after $\mathrm{EC}$ and $\mathrm{pH}$ was measured using EC and pH-meter (Masulili et al., 2010). To determine $P$ and $K$ soil samples were digested using hydrochloric and nitric acid (Cottenie et al., 1982), while for $\mathrm{N}$ determination another mixture of acids were used for digestion as described by Jones J. Benton. (1991). Nutrients accumulated in tubers were determined af- 
Table 2: Chemical characteristics of materials used in the experiment

\begin{tabular}{|c|c|c|c|c|c|}
\hline Parameter & FYM & Compost & $\mathrm{BC}$ & BC-FYM & BC-S \\
\hline $\mathrm{EC} \mu \mathrm{S} \mathrm{cm}^{-1}$ & 456 & 2080 & 1085 & 846 & 818 \\
\hline $\mathrm{pH}$ & 7.00 & 7.6 & 7.6 & 7.4 & 6.9 \\
\hline OC \% & 34.80 & 12.5 & 38.20 & 37.78 & 36.63 \\
\hline $\mathrm{C}: \mathrm{N}$ ratio & 24.26 & 12.5 & 509.3 & 47.52 & 466.6 \\
\hline $\mathrm{N} \%$ & 1.40 & 1.00 & 0.075 & 0.795 & 0.0785 \\
\hline $\mathrm{P} \%$ & 0.071 & 0.41 & 0.074 & 0.136 & 0.044 \\
\hline K \% & 0.085 & 0.32 & 0.003 & 0.042 & 0.002 \\
\hline $\mathrm{Fe} \%$ & 1.90 & 0.35 & 1.21 & 0.906 & 0.61 \\
\hline Mn mg kg-1 & 423.60 & 61.9 & 257.75 & 269.70 & 121.65 \\
\hline $\mathrm{Zn} \mathrm{mg} \mathrm{kg}{ }^{-1}$ & 77.25 & 79.2 & 81.25 & 107.15 & 0.60 \\
\hline $\mathrm{Cu} \mathrm{mg} \mathrm{kg}{ }^{-1}$ & 39.40 & 24.1 & 45.35 & 43.30 & 30.55 \\
\hline $\mathrm{B} \mathrm{mg} \mathrm{kg}{ }^{-1}$ & 19.15 & 32.6 & 14.40 & 14.00 & 8.30 \\
\hline
\end{tabular}

ter digestion using mixture of sulfuric and perchloric acid (5:1). P was determined in the solution digested using inductively coupled plasma (ICP- JY ULTIMA). Chemical analysis results for materials used are in $\mathrm{Ta}$ ble 2 .

\subsubsection{Quantitative determination of surface acidic groups}

Biochar surface acid functional groups were determined according to the description of Boehm titration method (Boehm et al., 1964 and Mukherjee et al., 2011). Briefly, about $0.5 \mathrm{~g}$ of coarse biochar sample was added to $50 \mathrm{ml}$ of each of three $0.05 \mathrm{M}$ bases of
$\mathrm{NaHCO}_{3}, \mathrm{Na}_{2} \mathrm{CO}_{3}$ and $\mathrm{NaOH}$. Then, the mixtures beside control solution without any material were shaken for $24 \mathrm{~h}$. Thereafter, the mixtures were filtered through a 42 Whatman filter paper to remove solids. Then, a 1 $\mathrm{ml}$ of suspension from each filtrate was added to $10 \mathrm{ml}$ of $\mathrm{HCl}(0.05 \mathrm{M})$ to guarantee complete neutralization of bases and then back-titrated with $\mathrm{NaOH}(0.05 \mathrm{M})$. Phenolphthalein color indicator was used to identify the endpoint. The total surface acidity was calculated as the moles neutralized by $\mathrm{NaOH}$, and the carboxylic acid groups as the moles neutralized by $\mathrm{NaHCO}_{3}$, and the lactonic groups as those neutralized by $\mathrm{Na}_{2} \mathrm{CO}_{3}$. The difference between moles neutralized by $\mathrm{NaOH}$ and $\mathrm{Na}_{2} \mathrm{CO}_{3}$ was considered as phenolic groups content (Rutherford et al., 2007).

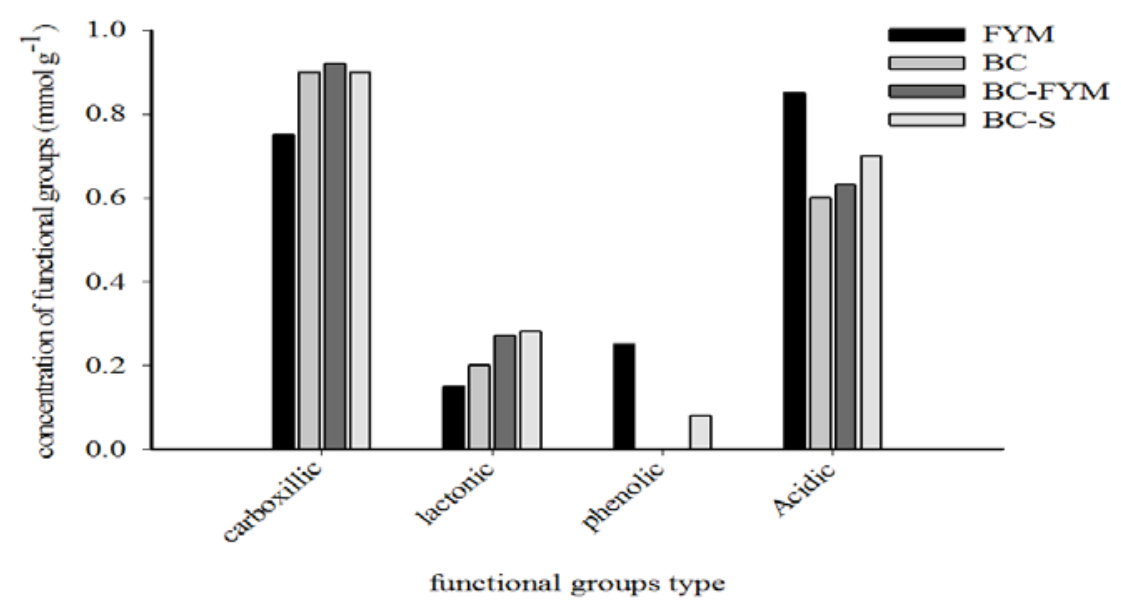

Figure 2: Functional groups concentration on the surface of used materials 


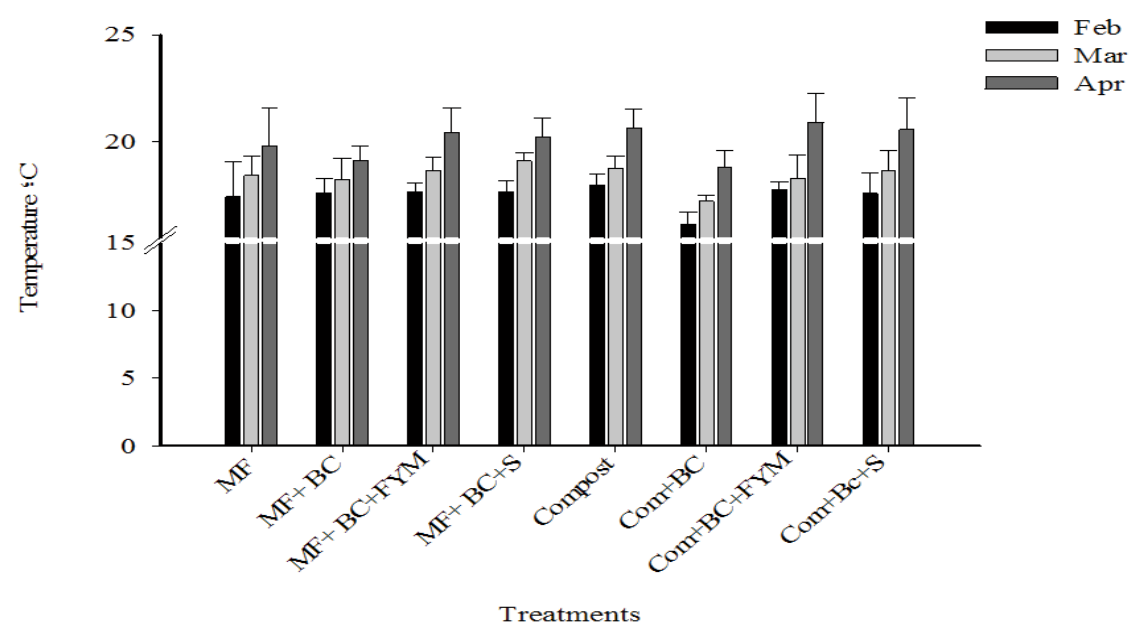

Figure 3: Influence of biochar on soil temperature during three months of potato cultivation in alkaline soil

\subsubsection{Determination of total carbohydrates}

Acid hydrolysis of tubers $(0.2 \mathrm{~g})$ was done in sealed tube using $10.0 \mathrm{ml} \mathrm{H}_{2} \mathrm{SO}_{4}$ solution $(1.0 \mathrm{M})$. The sealed tubes were boiled in water bath for $10 \mathrm{~h}$. After complete hydrolysis, suspension was neutralized by a known amount of barium carbonate and the precipitate was filtered through whatman No.1 filter paper. The filtrate was made up to a known volume. Total carbohydrates were determined in acid using phenol-sulfuric acid method as described by Dobois et al. (1965) as follows: A known volume of filtrate $(1.0 \mathrm{ml})$ was transferred into a clean dry test tube. $1.0 \mathrm{ml}$ of phenol solution (5\%) and $5.0 \mathrm{ml}$ of $\mathrm{H}_{2} \mathrm{SO}_{4}$ were added. The yellow orange color was measured at $490 \mathrm{~nm}$ using spectrophotometer against blank.

\section{RESULTS AND DISCUSSION}

\subsection{BIOCHAR CHARACTERIZATION}

Yield of BC (as the mass ratio of biochar recovered after pyrolysis and the initial feedstock) was approximately $35 \%$, while BC carbon content was recorded $38.2 \%$. Biochar pH (extracted according to Masulili et al., 2010) was slightly decreased using FYM and S from 7.6 for BC to 7.4 and 6.9 for BC-FYM and BC-S, respectively. These finding were already proven by Boehm titration method which is commonly used technique to determine the acidic oxygen surface functional groups on carbon samples. The total acidic groups were slightly higher in BC-S and BC-FYM than BC (Fig. 2). This was attributed to the acidic products resulted from decomposition of FYM or formation of $\mathrm{SO}_{4}=$ anions during hydra- tion of sulfur in BC-FYM and BC-S, respectively. This might explain how $\mathrm{pH}$ values of $\mathrm{BC}-\mathrm{FYM}$ and $\mathrm{BC}-\mathrm{S}$ were decreased compared to $\mathrm{BC}$ alone.

\subsection{INFLUENCE OF BIOCHAR APPLICATION ON SOIL PROPERTIES.}

\subsubsection{Soil temperature}

McCormack et al. (2013) reported that biochar enhances soil microbial activity by enhancing soil aggregation and porosity, $\mathrm{pH}$, moisture retention and soil temperature, as well as nutrient retention. This work studies the effect of $\mathrm{BC}$ and modified-BC application on soil properties such as nutrient availability, soil temperature and chemical characteristics. The influence of different treatments of biochar on soil temperature during field study is shown in Fig. 3. Soil temperature was measured monthly during potato growing season (Quartz digi-thermo thermometer). The results revealed that soil temperature was higher using BC-FYM and BC-S by 0.9 to $2.1{ }^{\circ} \mathrm{C}$ as compared with control or biochar only. This might be attributed to the high energy release during decomposition of FYM or sulfuric acid that resulted from hydration of sulfur. It was also mentioned that biochar has positive effect on soil biota (Lehmann et al., 2011; Warnock et al., 2007) which might increase soil temperature. In general, soil temperature has an important role creating a healthier and more active soil environment. Soil biota plays an important role in soil nutrient cycling (McLaughlin et al., 1988; Frossard et al., 2000). Phosphate-solubilizing bacteria enhance $P$ transfer from soil to plants: soil biota may contain a significant amount of P, typically $10-50 \mathrm{~kg}$ 


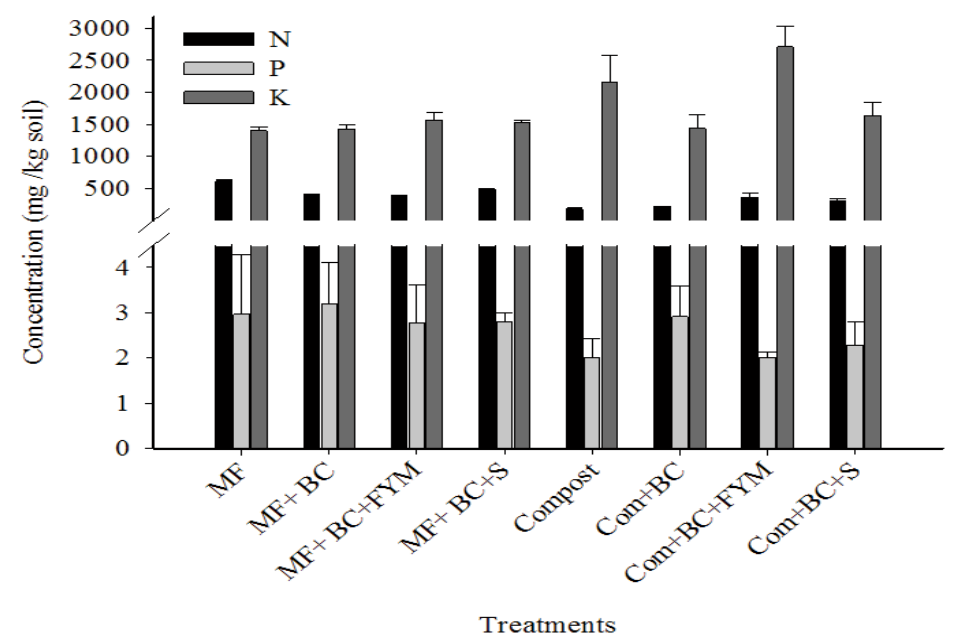

Figure 4: The influence of biochar and modified biochar on nutrient availability of macronutrients in alkaline soil cultivated with potatoes

$\mathrm{P}_{\text {ha }}{ }^{-1}$, or $1-10 \%$ of the total $\mathrm{P}$, and around $10-15 \%$ of soil organic P (Brookes et al., 1984; Richardson, 2001), so soil biota considered a major factor controlling organic and inorganic $\mathrm{P}$ concentrations in temperate soils (Seeling and Zasoski, 1993). All these findings showed that BC plays an important role in nutrient availability and yield due to its effect on soil temperature and soil biota. Soil temperature increased from February to April due to climatic conditions (Fig. 3).

\subsubsection{Soil nutrient availability}

Glaser et al. (2002) and Lehmann et al. (2011) re- ported that biochar used as a soil amendment to enhance soil fertility and plant growth, since it has shown potential as a sustainable amendment to improve chemical properties of soil. BC also was found to have a positive effect on soil nutrient availability (Mengel and Kirkby, 2001). In this study we investigate effect of biochar treatments on soil nutrients availability during field study on potatoes. Available NPK were measured in soil 70 days after planting (Fig. 4). The results revealed in general, that using solely biochar lowered the nutrient availability in soil, since biochar application generally raises soil $\mathrm{pH}$ (Hass et al., 2012) which reduces the availability of nutrients in alkaline soil. Modified biochar (BC-FYM or BC-S) showed higher nutrient availability than control despite the sig-

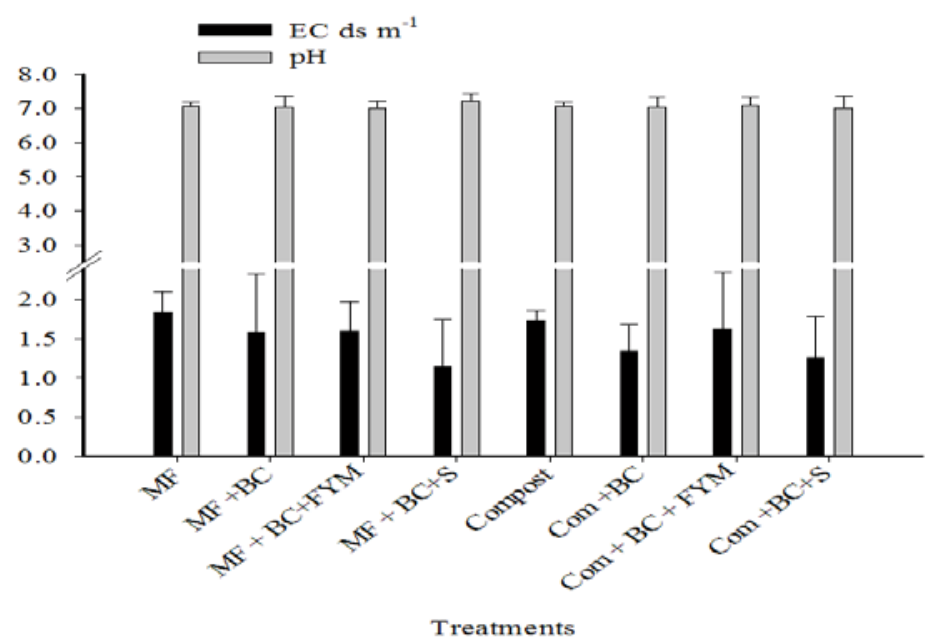

Figure 5: Influence of BC addition onto soil characteristics (EC and $\mathrm{pH}$ ) 
nificance was low in some cases. This might be attributed to excess of the amount of nutrients that exist in FYM composted with biochar or/and decomposition of organic matter or sulfur had led to decrease of soil $\mathrm{pH}$ which release more nutrients adsorbed or precipitated into soil solution. Biochar was also found to have an important role in fertilizer use efficiency due to adsorption of nutrients on its surface and keep it from leaching (Blackwell et al., 2010; Laird et al., 2010). In addition, BC was found to improve soil biota, such as arbuscular mycorrhizal fungi (AMF), which enhance nutrient availability in soil (Warnock et al., 2007).

\subsubsection{Chemical characteristics}

Figure 5 shows the influence of materials studied application onto soil chemical characteristics (EC and $\mathrm{pH}$ ). The $\mathrm{pH}$ level of alkaline soils would be affected by biochar application and the possible increase of soil $\mathrm{pH}$ in alkaline soil is harmful for plant growth (Liu and Zhang, 2012). While the results revealed that $\mathrm{EC}$ and $\mathrm{pH}$ of soil weren't affected significantly by the addition of BC or modified BC (BC-FYM or BC-S). This was attributed to the amount of added $\mathrm{BC}$ amendment $\left(12 \mathrm{Mg} \mathrm{ha}^{-1}\right)$, which was not enough to change the $\mathrm{pH}$ number. These results were agreed with those obtained by Somchai-Butnan et al. (2015) who found that soil pH was not affected by biochar amendment except in the soil amended with the highest rate of flash carbonization (FC) biochar excess than $12 \mathrm{Mg} \mathrm{ha}^{-1}$. Biochar relatively reduced soil EC, this might be attributed to the high adsorption capacity of biochar which enhance the mutual form and reduce the soluble form of salts.

\subsection{INFLUENCE OF BIOCHAR APPLICATION ON PLANT CHARACTERISTICS.}

\subsubsection{Crop yield}

Influence of studied materials on the productivity of potatoes tubers is shown in Fig. 6. The results revealed that solely addition of biochar decreased the yield of potatoes more than $6 \%$ and $10 \%$ as compared with control using mineral and organic fertilization, respectively. This was attributed to the alkalinity effect of biochar which reduce the availability of some nutrients; consequently the total yield was reduced. These results are similar as those obtained by Van Zwieten et al. (2010), who reported that the application of biochar 1 with $\mathrm{pH}$ value of 9.4 and biochar 2 with $\mathrm{pH}$ value of 8.2 both increased the $\mathrm{pH}$ of ferrosol (initial $\mathrm{pH}$ at 4.2), but only biochar 2 increased the $\mathrm{pH}$ value of calcareous soil (initial $\mathrm{pH}$ at 7.67). Also Fellet et al. (2011) reported that application of $\mathrm{BC}$ in mine tailing soil had led to excess in soil $\mathrm{pH}$ from 8.13 to 10.2 at $10 \%$ biochar application rate. Treatment BC-FYM resulted in yield increase for 11 and $25 \%$ in both mineral and organic fertilization. This was similar to the results reported by Glaser et al. (2002) who concluded the fact that crop yield is increased using biochar combined with mineral or organic fertilizers. BC-FYM application with organic fertilization produced higher yield than mineral fertilization due to the acidity effect of compost which decreases alkalinity of BC. It benefits in releasing nutrients slowly in available form for plant absorption during growth period. This led to minimizing nutrient leaching from soil rather than mineral fertilization. Also, we found that the yield was much higher using BC-FYM than BC-S with both types of fertigation. This

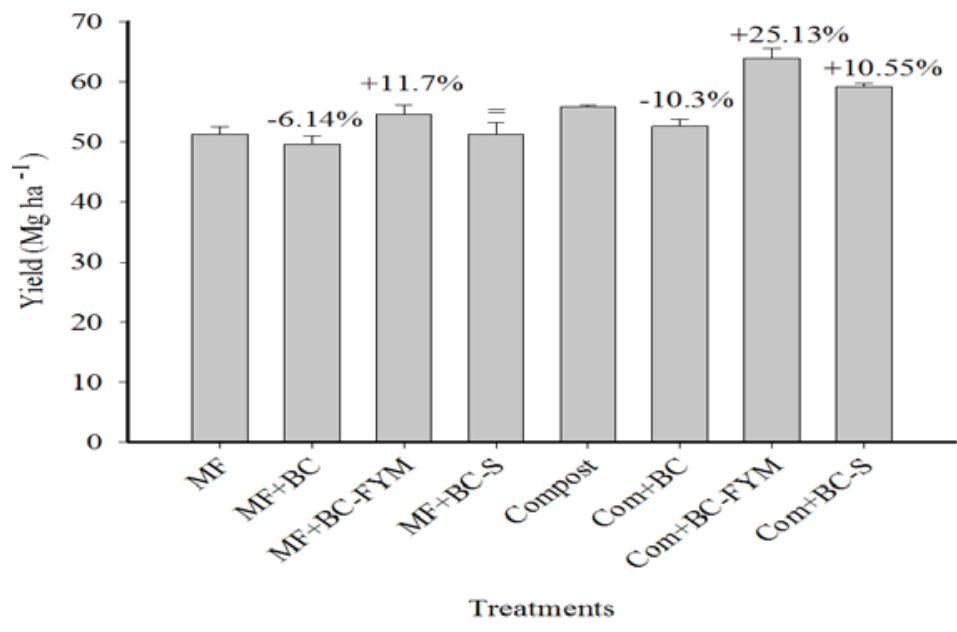

Figure 6: Biochar addition efficacy on yield of potato tubers cultivated in alkaline soil 


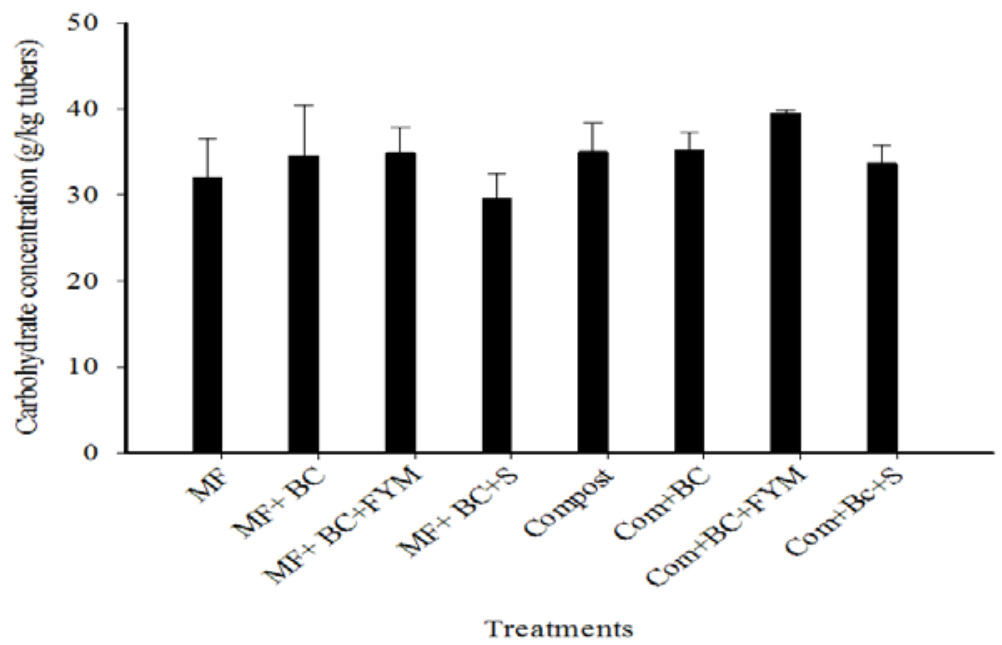

Figure 7: Biochar addition efficacy on carbohydrate concentration of potatoes tubers cultivated in alkaline soil

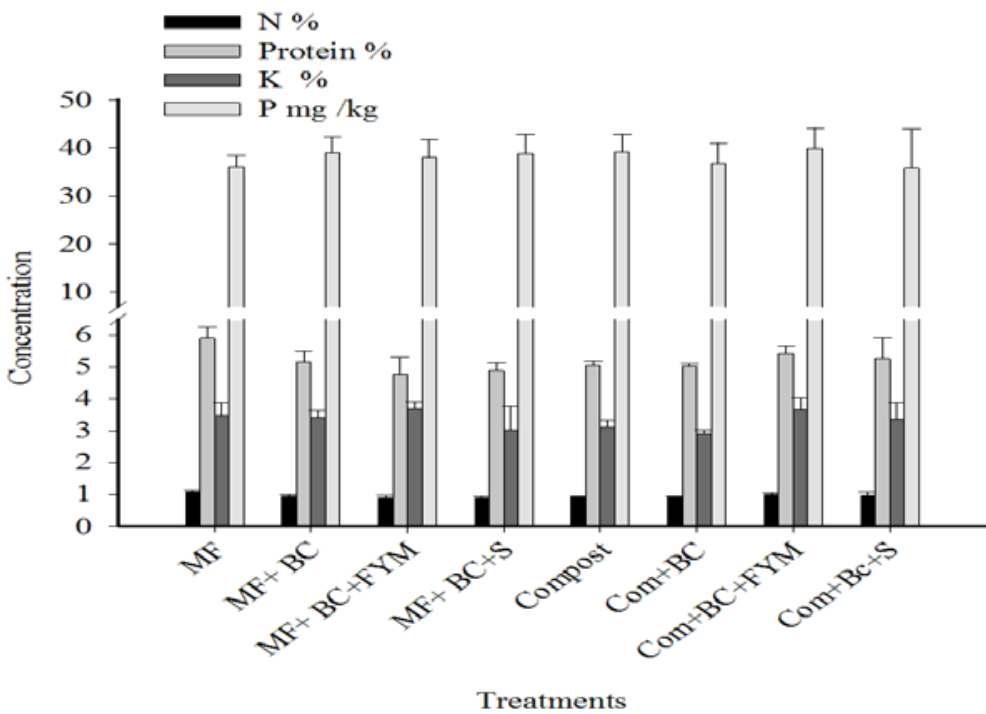

Figure 8: Biochar addition efficacy on content of macronutrients in tubers

might be attributed to the additional amounts of $\mathrm{N}$ exist in BC-FYM and/or higher nutrient availability due to higher microbial activity, such as arbuscular mycorrhizal fungi (AMF) (Warnock et al., 2007). So we recommend using $\mathrm{BC}$ in alkaline soils after composting with FYM to enhance crop productivity and soil chemical characteristics. More work is needed to state the adequate amount of $\mathrm{BC}$ added.

\subsubsection{Yield component}

Total carbohydrates in potatoes tubers were measured to study the efficiency of biochar addition on yield component grown in alkaline soil compared with modified biochar (BC-FYM or BC-S) (Figure 7). Total carbohydrate was significantly increased using BC-FYM or BC-S as compared with using BC solely, while there wasn't any significance with control. This was attributed to the excess amount of potassium in FYM found in BCFYM, which are responsible for carbohydrate transferring from leaves to tubers. Since $B C$ has a high adsorption capacity for K ions (Lehmann et al., 2003) because of its high porosity and surface/volume ratio and can improve plant nutrients uptake and $\mathrm{P}, \mathrm{Ca}, \mathrm{K}$ availability (Chan et al., 2007; Yamato et al., 2006). Elemental concentration of $\mathrm{N} \mathrm{P} \mathrm{K} \mathrm{in} \mathrm{potatoes} \mathrm{tubers} \mathrm{weren't} \mathrm{significantly} \mathrm{affected} \mathrm{by}$ biochar treatments (Fig. 8). Consequently, protein con- 
tent wasn't also affected by biochar addition, with the exception of BC-FYM and BC-S using organic fertilization where a significant increase in tubers protein content was measured than in control and BC solely.

\section{CONCLUSION}

Biochar proved to enhance soil chemical and physical properties, while this effect was negative in alkaline soils since literature reported that $\mathrm{BC}$ raise soil $\mathrm{pH}$. Composting biochar with other materials (FYM and Sulfur) was suggested to modify biochar action in alkaline soil. A field experiment was conducted using modified BC (BC-FYM or BC-S) compared with BC solely addition to alkaline soils under mineral and organic fertilization. BC-FYM proved to be the best treatment, since BC-FYM increased crop yield of potatoes 11 and $25 \%$ compared to control under mineral and organic fertilizers, respectively. BC-FYM was recorded higher amount of carbohydrate and protein as compared with BC solely especially under organic fertilization. Yield content of elements $(\mathrm{N}$ $\mathrm{P} \mathrm{K}$ ) in potatoes tubers weren't affected significantly with biochar application as found in carbohydrate concentration. So we recommend composting biochar with FYM before using it in the alkaline soil to enhance crop productivity and soil chemical characteristics. More work is needed to state the adequate amount of BC added.

\section{REFERENCES}

Abdelhafez, A.A., Li, J. \& Abbas, M.H.H. (2014). Feasibility of biochar manufactured from organic wastes on the stabilization of heavy metals in a metal smelter contaminated soil. Chemosphere, 117, 66-71.https://doi.org/10.1016/j.chemosphere.2014.05.086

Alburquerque, J.A., Salazar, P., Barrón, V., Torrent, J., Campillo, M.C., Gallardo, A. \& Villar, R. (2012). Enhanced wheat yield by biochar addition under different mineral fertilization levels. Agronomy Sustainable Development, 33(3), 475484. https://doi.org/10.1007/s13593-012-0128-3

American Standard of Testing Material. (2001). Standard Test Method for Chemical Analysis of Wood Charcoal. ASTM D 1762-84.

Asai, H., Samson, B. K., Stephan, H. M., Songyikhangsuthor, K., Homma, K., Kiyono, Y., Inoue, Y., Shiraiwa, T. \& Horie, T. (2009). Biochar amendment techniques for upland rice production in northern Laos. Field Crops Research, 111, 8184. https://doi.org/10.1016/j.fcr.2008.10.008

Atkinson, C.J., Fitzgerald, J.D. \& Hipps, N.A. (2010). Potential mechanisms for achieving agricultural benefits from biochar application to temperate soils: a review. Plant Soil, 337, 1-18. https://doi.org/10.1007/s11104-010-0464-5

Baronti, S., Vaccari, F.P., Miglietta, F., Calzolari, C., Lugato, E., Orlandini, S., Pini, R.,Zulian, C. \& Genesio, L. (2014).
Impact of biochar application on plant water relations in Vitis vinifera L.. European Journal of Agronomy, 53, 38-44. https://doi.org/10.1016/j.eja.2013.11.003

Bateman, E. J., \& Baggs, E. M. (2005). Contributions of nitrification and denitrification to $\mathrm{N} 2 \mathrm{O}$ emissions from soils at different water-filled pore space. Biology and Fertility of Soils, 41, 379- 388. https://doi.org/10.1007/s00374-005-0858-3

Blackwell, P., Krull, E., Butler, G., Herbert, A. \& Solaiman, Z. (2010). Effect of banded biochar on dry land wheat production and fertilizer use in south-western Australia: an agronomic and economic perspective. Australian Journal of Soil Research, 48, 531-545. https://doi.org/10.1071/SR10014

Boehm, H.P., Diehl, E., Heck, W. \& Sappok, R. (1964). Surface oxides of carbon. Angewandte Chemie International Edition, 3, 669-77. https://doi.org/10.1002/anie.196406691

Borchard, N., Prost, K., Kautz, T., Moeller, A. \& Siemens, J. (2012). Sorption of copper (II) and sulphate to different biochar before and after composting with farm yard manure. European Journal of Soil Science, 63, 399-409. https://doi. org/10.1111/j.1365-2389.2012.01446.x

Brookes, P.C., Powlson, D.S. \& Jenkinson, D.S. (1984). Phosphorus in the soil microbial biomass. Soil Biology and Biochemistry, 16,169-175. https://doi.org/10.1016/00380717(84)90108-1

Bruun, E.W., Müller-Stöver, D., Ambus, P. \& HauggaardNielsen, H. (2011). Application of biochar to soil and N2O emissions: potential effects of blending fast-pyrolysis biochar with anaerobically digested slurry. European Journal of Soil Science, 62, 581-589. https://doi.org/10.1111/j.13652389.2011.01377.x

Busch, D., Kammann, C., Grünhage, L. \& Müller, C. (2012). Simple biotoxicity tests forevaluation of carbonaceous soil additives: establishment and reproducibility offour test procedures. Journal of Environmental Quality, 41, 1023. https:// doi.org/10.2134/jeq2011.0122

Buss, W., Kammann, C. \& Koyro, H.W. (2012). Biochar reduces copper toxicity in Chenopodium quinoa Willd. in a sandy soil. Journal of Environmental Quality, 41, 1157. https://doi. org/10.2134/jeq2011.0022

Busscher, W.J., Novak, J.M., Evans, D.E., Watts, D.W., Niandou, M.A.S. \& Ahmedna, M. (2010). Influence of pecan biochar on physical properties of a Norfolk loamy sand. Soil Science, 175, 10-14. https://doi.org/10.1097/SS.0b013e3181cb7f46

Butnan, S., Deenik, J.L., Toomsan, B., Antal, M.J. \& Vityakon, P. (2015). Biochar characteristics and application rates affecting corn growth and properties of soils contrasting in texture and mineralogy. Geoderma, 237-238, 105-116. https:// doi.org/10.1016/j.geoderma.2014.08.010

Case, S.D.C., McNamara, N.P., Reay, D.S. \& Whitaker, J. (2012). The effect of biochar addition on $\mathrm{N} 2 \mathrm{O}$ and $\mathrm{CO} 2$ emissions from a sandy loam soil - the role of soil aeration. Soil Biology and Biochemistry, 51,125-34. https://doi.org/10.1016/j. soilbio.2012.03.017

Cayuela, M.L., Sánchez-Monedero, M.A., Roig, A., Hanley, K., Enders, A. \& Lehmann, J. (2013). Biochar and denitrification in soils: when, how much and why does biochar reduce N2O emissions? Scientific Reports, 3, 1732. https://doi. org/10.1038/srep01732

Chan K.Y., Van Zwieten L., Meszaros I., Downie A. \& Joseph S. 
(2007). Agronomic values of green waste biochar as a soil amendment. Australian Journal of Soil Research, 45, 629634. https://doi.org/10.1071/SR07109

Cheng, C.-H. \& Lehmann, J. (2009). Ageing of black carbon along a temperature gradient. Chemosphere, 75, 1021-1027. https://doi.org/10.1016/j.chemosphere.2009.01.045

Clough, T., Condron, L., Kammann, C. \& Müller, C. (2013). A review of biochar and soil nitrogen dynamics. Agronomy, 3, 275-293. https://doi.org/10.3390/agronomy3020275

Cottenie A., Verloo, M., Kiekens, 1., Velghe, G. \& Camerlynck, R. (1982). Chemical Analysis of Plants and Soils. Lab. of Analytical and Agro. State, University Ghent. Belgium.

Ding, W., Meng, L., Yin, Y., Cai Z. \& Zheng, X. (2007). CO2 emission in an intensively cultivated loam as affected by long term application of organic manure and nitrogen fertilizer. Soil Biology and Biochemistry, 39, 669-679. https:// doi.org/10.1016/j.soilbio.2006.09.024

Ding, Y., Liu, Y.X., Wu, W.X., Shi, D.Z., Yang, M. \& Zhong, Z.K. (2010). Evaluation of Biochar effects on nitrogen retention and leaching in multi-layered soil columns. Water Air Soil Pollution, 213, 47-55. https://doi.org/10.1007/s11270-0100366-4

Dubois, M., Cilles, K.A., Hamilton, J.K., Rober, P.A. \& Smith, F. (1965). Colorimetric method for determination of sugars related substances. Analytical Chemistry, 28, 350-365. https://doi.org/10.1021/ac60111a017

Fellet, G., Marchiol, L., DelleVedove, G. \& Peressotti, A. (2011). Application of biochar on mine tailings: Effects and perspectives for land reclamation. Chemosphere, 83, 12621267. https://doi.org/10.1016/j.chemosphere.2011.03.053

Fischer, D. \& Glaser, B. (2012). Synergisms between compost and biochar for sustain-able soil amelioration. In: Kumar, S., Bharti, A. (Eds.), Management of Organic Waste. Rijeka, In Tech., 167-198. https://doi.org/10.5772/31200

Frossard, E., Condron, L.M., Oberson, A., Sinaj, S. \& Fardeau, J.C. (2000). Processes governing phosphorus availability in temperate soils. Journal of Environmental Quality, 29, 15-23. https://doi.org/10.2134/jeq2000.00472425002900010003x

Gathorne-Hardy, A., Knight, J. \& Woods, J. (2009). Biochar as a soil amendment positively interacts with nitrogen fertiliser to improve barley yields in the UK. IOP Conf. Ser. Earth. Environmental Science, 6, 372052. https://doi. org/10.1088/1755-1307/6/37/372052

Glaser, B., Lehmann, J. \& Zech, W. (2002). Ameliorating physical and chemical properties of highly weathered soils in the tropics with charcoal - a review. Biology and Fertility of Soils, 35, 219-230. https://doi.org/10.1007/s00374-0020466-4

Gomez-Eyles, J.L., Beesley, L., Moreno-Jiménez, E., Ghosh, U. \& Sizmur, T. (2013). The potential of biochar amendments to remediate contaminated soils. In: Ladygina, N., Rineau, F. (Eds.), Biochar and Soil Biota. CRC Press, Boca Raton. https://doi.org/10.1201/b14585-5

Graber, E.R. \& Elad, Y. (2013). Biochar Impact on Plant Resistance to Disease. CRC Press, Boca Raton. https://doi. org/10.1201/b14585-3

Graber, E.R., Tsechansky, L., Gerstl, Z. \& Lew, B. (2012). High surface area biochar negatively impacts herbicide effi- cacy. Plant Soil, 353(1-2), 95-106. https://doi.org/10.1007/ s11104-011-1012-7

Harsono, S. S., Grundmann, P. \& Siahaan, D. (2015). Role of Biogas and Biochar Palm Oil Residues for Reduction of Greenhouse Gas Emissions in the Biodiesel Production. Energy Procedia, 65, 344 - 351. https://doi.org/10.1016/j. egypro.2015.01.063

Hass, A., Gonzalez, J.M., Lima, I.M., Godwin, H.W., Halvorson, J.J. \& Boyer, D.G. (2012). Chicken manure biochar as liming and nutrient source for acid Appalachian soil. Journal of Environmental Quality, 41, 1096-1106. https://doi. org/10.2134/jeq2011.0124

Husson, O. (2012). Redox potential (Eh) and pH as drivers of soil/plant/microorganism systems: a trans disciplinary overview pointing to integrative opportunities for agronomy. Plant Soil, 362, 389-417. https://doi.org/10.1007/ s11104-012-1429-7

Ippolito, J.A., Laird, D.A. \& Busscher, W.J. (2012). Environmental benefits of biochar. Journal of Environmental Quality, 41, 967. https://doi.org/10.2134/jeq2012.0151

Jin, H. (2010). Characterization of Microbial Life Colonizing Biochar and Biochar-Amended Soils. Cornell University Graduate School.

Jones J.B. (1991). Kjeldahl Method for Nitrogen Determination. Athens, GA: Micro- Macro Publishing,

Joseph, S., Graber, E., Chia, C., Munroe, P., Donne, S., Thomas, T., Nielsen, S., Marjo, C., Rutlidge, H., Pan, G., Li, L., Taylor, P., Rawal, A. \& Hook, J. (2013a). Shifting paradigms: development of high-efficiency biochar fertilizers based on nano-structures and soluble components. Carbon Management, 4, 323-343. https://doi.org/10.4155/cmt.13.23

Joseph, S., Van Zwieten, L., Chia, C., Kimber, S., Munroe, P., Lin, Y., Marjo, C., Hook, J.,Thomas, T., Nielsen, S., Donne, S. \& Taylor, P. (2013b). Designing Specific Biochars to Address Soil Constraints: A Developing Industry. In: Ladygina, N., Rineau, F. (Eds.), Biochar and Soil Biota. CRC Press, Boca Raton. https://doi.org/10.1201/b14585-7

Kammann, C., Ratering, S., Eckhard, C. \& Muller, C. (2012). Biochar and hydrochar effects on greenhouse gas (carbon dioxide, nitrous oxide, and methane) fluxes from soils. Journal of Environmental Quality, 41, 1052-66. https://doi. org/10.2134/jeq2011.0132

Karhu, K., Mattila, T., Bergström, I. \& Regina, K. (2011). Biochar addition to agricultural soil increased $\mathrm{CH} 4$ uptake and water holding capacity - results from a short-term pilot field study. Agriculture, Ecosystems \& Environment, 140, 309-13. https://doi.org/10.1016/j.agee.2010.12.005

Laird, D., Fleming, P., Wang, B., Horton, R. \& Karlen, D. (2010). Biochar impact on nutrient leaching from a Midwestern agricultural soil. Geoderma, 158, 436-442. https://doi. org/10.1016/j.geoderma.2010.05.012

Lehmann J., Da Silva J.P. jr., Steiner C., Nehls T., Zech W. \& Glaser B. (2003). Nutrient availability and leaching in an archaeological anthrosol and a ferralsol of the Central Amazon basin: fertilizer, manure and charcoal amendments. Plant Soil, 249, 343-357. https://doi.org/10.1023/A:1022833116184

Lehmann, J., Gaunt, J. \& Rondon, M. (2006). Bio-char sequestration in terrestrial ecosystems-a review. Mitigation and 
Adaptation Strategies for Global Change, 11, 403-427. https://doi.org/10.1007/s11027-005-9006-5

Lehmann, J., Rillig, M., Thies, J., Masiello, C., Hockaday, W. \& Crowley, D. (2011). Biochar effects on soil biota - a review. Soil Biology and Biochemistry, 43, 1812-1836. https://doi. org/10.1016/j.soilbio.2011.04.022

Lehmann, J. \& Steiner, C. (2009a). Amazonian Dark Earths: Wim Sombroek's Vision. Springer Netherlands, Dordrecht.

Lehmann, J. \& Steiner, J. (2009b). Biochar for Environmental Management. Published by Earth scan Publishers Ltd (ISBN 978-1-84407-658-1).

Liu, X.H. \& Zhang, X.C. (2012). Effect of biochar on pH of alkaline soils in the Loess Plateau: Results from incubation experiments. International Journal of Agriculture and Biology, 4, 745-750.

Major, J., Rondon, M., Molina, D., Riha, S.J. \& Lehmann, J. (2010). Maize yield and nutrition during 4 years after biochar application to a Colombian savanna oxisol. Plant Soil, 333, 117-128. https://doi.org/10.1007/s11104-010-0327-0

Masulili, A., Utomo, W.H. \& Syechfani, M.S. (2010). Rice Husk Biochar for Rice Based Cropping System in Acid Soil 1. The Characteristics of Rice Husk Biochar and Its Influence on the Properties of Acid Sulfate Soils and Rice Growth in West Kalimantan, Indonesia. Journal of Agricultural Science, 2(1), 39-47. https://doi.org/10.5539/jas.v2n1p39

McCormack, S.A., Ostle, N., Bardgett, R.D., Hopkins, D.W. \& Vanbergen, A.J. (2013). Biochar in bioenergy cropping systems: impacts on soil faunal communities and linked ecosystem processes. GCB Bioenergy, 5, 81-95. https://doi. org/10.1111/gcbb.12046

Mclaughlin, M.J., Alston, A.M. \& Martin, J.K. (1988). Phosphorus cycling in wheat pasture rotations .II. The role of the microbial biomass in phosphorus cycling. Australian Journal of Soil Research, 26(2), 333 - 342. https://doi. org/10.1071/SR9880333

Mengel, K. \& Kirkby, E.A. (2001). Principles of Plant Nutrition, 5th edition. Kluwer Academic Publishers, Dordrecht. https://doi.org/10.1007/978-94-010-1009-2

Mukherjee, A., Zimmerman, A.R. \& Harris, W. (2011). Surface chemistry variations among a series of laboratoryproduced biochars. Geoderma, 136, 247-255. https://doi. org/10.1016/j.geoderma.2011.04.021

Nishio, M. (1996). Microbial Fertilizers in Japan. FFTC Extension Bulletin. Food and Fertilizer Technology Center, Taipei City.

Pietikäinen, J., Kiikkilä, O. \& Fritze, H. (2003). Charcoal as a habitat for microbes and its effect on the microbial community of the underlying humus. Oikos, 89,231-242. https:// doi.org/10.1034/j.1600-0706.2000.890203.x

Prost, K., Borchard, N., Siemens, J., Kautz, T. \& Séquaris, J. (2012). Biochar affected by composting with farmyard manure. Journal of Environmental Quality, 42(1), 164-172. https://doi.org/10.2134/jeq2012.0064

Richardson, A.E. (2001). Prospects for using soil microorganisms to improve the acquisition of phosphorus by plants. Australian Journal of Plant Physiology, 28, 897-906. https:// doi.org/10.1071/PP01093

Rondon, M., Lehmann, J., Ramírez, J. \& Hurtado, M. (2007). Biological nitrogen fixation by common beans (Phaseo- lus vulgaris L.) increases with bio-char additions. Biology and Fertility of Soils, 43, 699-708. https://doi.org/10.1007/ s00374-006-0152-Z

Rutherford, D.W., Wershaw, R.L. \& Reeves, J.B. (2008). Development of acid functional groups and lactones during the thermal degradation of wood and wood components. Denver: U.S. Department of the Interior, U.S. Geological Survey, 2007- 5013. https://doi.org/10.3133/sir20075013

Schulz, H., Dunst, G. \& Glaser, B. (2014). No Effect Level of CoComposted Biochar on Plant Growth and Soil Properties in a Greenhouse Experiment. Agronomy, 4, 34-51. https://doi. org/10.3390/agronomy4010034

Seeling, B. \& Zasoski, R.J. (1993). Microbial effects in maintaining organic and inorganic solution phosphorus concentrations in a grass land topsoil. Plant Soil, 148, 277-284. https://doi.org/10.1007/BF00012865

Steiner, C., Das, K.C., Melear, N. \& Lakly, D. (2010). Reducing nitrogen loss during poultry litter composting using biochar. Journal of Environmental Quality, 39, 1236. https:// doi.org/10.2134/jeq2009.0337

Steiner, C., Teixeira, W.G., Lehmann, J., Nehls, T., de Macedo, J.L.V., Blum, W.E.H. \& Zech, W. (2007). Long term effects of manure, charcoal and mineral fertilization on crop production and fertility on a highly weathered central Amazonian upland soil. Plant and Soil, 291, 275-290. https://doi. org/10.1007/s11104-007-9193-9

Taghizadeh-Toosi, A., Clough, T.J., Sherlock, R.R. \& Condron, L.M. (2011). Biochar adsorbed ammonia is bioavailable. Plant Soil, 57-69. https://doi.org/10.1007/s11104-0110870-3

Tan, W.L, Rosenani, A.M, Ahmad, S.H. \& Ishak, C.F. (2012). Oil palm empty fruit bunch biochar: characterization and potential usage as soil amendment for its nutrient retention capacity in soil, The 4th International Biochar Congress, 12.

Tuomela, M., Vikman, M., Hatakka, A. \& Itävaara, M. (2000). Biodegradation of lignin in a compost environment: a review. Bioresource Technology, 72,169-183. https://doi. org/10.1016/S0960-8524(99)00104-2

Van Zwieten, L., Kimber, S., Morris, S., Chan, K.Y., Downie, A., Rust, J., Joseph, S. \& Cowie, A. (2010). Effects of biochar from slow pyrolysis of papermill waste on agronomic performance and soil fertility. Plant Soil, 327, 235-246. https:// doi.org/10.1007/s11104-009-0050-X

Ventura, M., Sorrenti, G., Panzacchi, P., George, E. \& Tonon, G. (2013). Biochar reduces short-term nitrate leaching from a horizon in an apple orchard. Journal of Environmental Quality, 42, 76-82. https://doi.org/10.2134/jeq2012.0250

Verheijen, F.G.A., Jeffery, S., Bastos, A.C., van der Velde, M. \& Diafas, I. (2010). Biochar Application to Soils - A Critical Scientific Review of Effects on Soil Properties, Processes and Functions. EUR 24099 EN, Luxembourg.

Warnock, D., Lehmann, J., Kuyper, T. \& Rillig, M. (2007). Mycorrhizal responses to biochar in soil - concepts and mechanisms. Plant Soil, 300, 9-20. https://doi.org/10.1007/ s11104-007-9391-5

Yamato M., Okimori Y., Wibowo I.F., Anshori S. \& Ogawa M. (2006). Effects of the application of charred bark of Acacia mangium on the yield of maize, cowpea and peanut, and soil chemical properties in South Sumatra, Indonesia. 
Soil Science and Plant Nutrition, 52, 489-495. https://doi org/10.1111/j.1747-0765.2006.00065.x

Yuan, J.H. \& Xu, R.K. (2011). The amelioration effects of low temperature biochar generated from nine crop residues on an acidic ultisol. Soil Use and Management, 27, 110- 115 https://doi.org/10.1111/j.1475-2743.2010.00317.x
Zimmerman, A.R. (2010). Abiotic and microbial oxidation of laboratory-produced black carbon (biochar). Environmental Science and Technology, 44, 1295-1301. https://doi. org/10.1021/es903140c 